\title{
Developing Critical Skills of Management Students in Operational Research's Course
}

\author{
Triman Juniarso ${ }^{1}$, Ninik Mutianingsih $^{2}$, Bisma Arianto $^{3 *}$, Lydia Lia Prayitno $^{4}$ \\ \{bismaarianto@gmail.com ${ }^{3}$ \} \\ FKIP, Universitas PGRI Adi Buana Surabaya, Indonesian ${ }^{1,2,4}$, Fakultas Ekonomi, Universitas PGRI \\ Adi Buana Surabaya, Indonesian ${ }^{3}$
}

\begin{abstract}
Student critical thinking can be developed through a learning process, application of problem-based learning. This study to describe the critical thinking skills of third management's students in research operational course. Students asked to intervene in a great variety of problem situations often characterized by high degrees of complexity and diversity Problem based learning able to develop critical thinking skills. This model able to teach students to use many concepts, principles, and skills to solve operational research problems. Data collection by researcher interacting directly with the research subject. The analysis used Facione (2006) describes critical thinking as a way for a person to regulate himself in judging something to produce interpretation, analysis, evaluation, inference, and presentation using evidence, concepts, methodologies, criteria, or contextual considerations that are used as the basis for doing decision-making. The results show that through learning based on operational research able to develop students' critical thinking skills, especially in terms of identifying, analyzing, solving problems, thinking logically, and drawing conclusions that are appropriate to the problem. This suggests that use problems that involve critical thinking of students in the learning process. The capacity of the HOTS is closely related to thinking processes while solving mathematics problems.
\end{abstract}

Keywords: critical thinking, students, management, operational research, ability

\section{Introduction}

Enhancement of human resources quality is one component to keep up industrial development 4.0. In this case, University an important role to make it happen through the Tri Darma of University, which focuses on preparing graduates to enter the world of the profession[1]. Universities must equip each student with critical thinking skills. Enhancement students' critical thinking skills can be developed through an active student learning process.

In order to compete nationally and internationally in the globalization era, there are some skills that must be required by the learners as a human resource[2] including:

a. thinking skills that include critical thinking, problem-solving, creativity, and metacognition;

b. communication and collaboration skills, able to communicate and collaborate effectively;

c. creativity and innovation skills, able to develop creativity to generate innovative breakthroughs;

d. information and communications technology literacy, able to utilize information and communication technologies to improve the performance and activities of daily life; 
e. contextual learning skills, capable of undergoing self-contextual learning activities as part of personal development; and

f. information and media literacy skills that are able to understand and use a variety of communication media to convey ideas, implement collaborative activities, and interaction with various parties.

Therefore, human resources should be able to think critically and creatively, use the technology and information that they obtained and also capable to interpret the meaning of information and being the independent learners.

Studies about critical thinking skills have been focused on by many researchers $[3][4][5][6]$. One of the studies shows that the enhancement of mathematical critical thinking skills of students learning with ordinary learning was significantly better than studying with the MEAs approach[3]. The other study shows that the development of e-modules that are oriented to problem-based learning to improve critical thinking skills[4]. The other researcher explains the ability that arises when implementing problem-based learning is the ability to identify, analyze, solve problems, think logically, and make decisions correctly and can draw conclusions[5]. And the others shows that critical thinking has a positive impact on the academic ability of magister[6].

From the several studies above, it shows that there is no research that discusses the critical thinking skills of S1 students, especially management students. One of the subjects studied in the S1 Management study program is Operational Research. Operations researchers work for and with a great variety of clients. They are asked to intervene in a great variety of problem situations often characterized by high degrees of complexity and diversity. They bring to these situations strong analytical and consultancy skills[7]. In fact, studying operational research students still, think theoretically, and are less able to develop critical thinking skills in themselves. The enthusiasm of students in giving responses given by lecturers is still very limited, students have not been able to develop their abilities and potential.

Critical thinking as a way for a person to regulate himself in judging something to produce interpretation, analysis, evaluation, inference, and presentation using evidence, concepts, methodologies, criteria, or contextual considerations that are used as the basis for doing decision-making[8]. Critical thinking is important because it can be used as a tool for inquiry. In addition, critical thinking can also be used as a strength and source of energy in one's social life and person.

Ideally, through lecture activities, able to develop reasoning abilities in students which are reflected through the ability to think critically, logically, systematically. In addition, after participating in lectures students must also be objective, honest, disciplined in solving good problems in various fields in their daily lives. So that in this study, researchers are interested in describing critical thinking skills of management students through research operational subjects.

\section{Method}

This is a descriptive study with a qualitative approach. The purpose of this study is to collect information that exists. This research was conducted in Management students, Faculty of Economics, University of PGRI Adi Buana Surabaya in the third semester. Next, the objects will be described in depth in the identified subjects with middle critical thinking skills. For the interview process carried out on subjects who are able to communicate well. 
This research was carried out through several stages, the preliminary stage by conducting preliminary analysis and drawing up the research design. Next, compile research supporting instruments, namely operational research's problems [9], answer guideline rubrics, and interview guidelines. The main instrument in this study is the researchers themselves who are supported by supporting instruments. The answer guideline rubric used is adjusted to the indicators of critical thinking skills of Facione, including interpretation, analysis, evaluation, inference, explanation, and self-regulation.

From the data collected, the researcher will determine the subject who has critical thinking skills who are interviewed. This is to clarify the test results from students. The data will be analyzed, which is used to support the description of management students' critical thinking skills through operational research subjects.

\section{Result and Analysis}

From the results of the initial test, researchers obtained one subject (AA) who had moderate critical thinking skills. The following will describe the critical thinking skills of management students in operational research subjects based on indicators of critical thinking skills.

\subsection{Interpretation}

AA begins to solve operational research problems, AA does not write down in full write down all the information given to the problem. To dig deeper information, researchers conducted interviews with the subject. The following are the results of interviews of researchers with the subject.

$P \quad$ : kenapa kamu bisa berfikir seperti ini? Kamu berfikir masalah ini untuk menentukan keuntungan maksimal perusahaan?

AA : Iya pak, biasanya masalah kaya gini nyari keuntungan pastinya maksimal kan ndak mungkin cari kerugian maksimal

$P \quad$ : kamu pernah ngerjakan soal seperti ini?

AA : kalo seperti ini, baru pertama kali

$\mathrm{P} \quad$ : why can you think like this?

Do you think this problem is to determine the company's maximum profit?

AA : Yes sir, it's usually a problem like this, so the maximum profit is definitely not possible to find maximum losses

$\mathrm{P}$ : Have you ever done a problem like this?

AA : if it's like this, it's the first time

Based on the interview, AA has not been able to interpret the problem properly. The subject only writes the outline of the problem given, but this inhibits the problem-solving process because the representation of the problem is a way to understand the problem and make a plan to solve the problem[10]. Use of different representations to be approved and support the process of thinking[11]. 


\subsection{Analysis}

AA's determine the concepts can be used to solve problems. Furthermore, AA conducts procedural calculations and in making mistakes in reading the mathematical operations used. AA has mastered the concept but has not been able to apply it properly to the problem given. AA made a mistake operating the symbol of mathematical operations because the subject should be able to interpret symbols well[12]. This important for student dominate HOTS, it needs to acquire a deep understanding of mathematical concepts and can be applied in real life. Students ability to develop the capacity of the HOTS is closely related to thinking processes while solving mathematics problems[13].

\subsection{Evaluation}

In evaluations, $\mathrm{AA}$ is able to evaluate the statements used to conclude the inference process. To explore further, the researcher interviewed AA regarding the evaluation process written in the answer sheet and quote for the interview as follows.

$P \quad$ : mengapa kamu bisa menentukan jumlah uang yang diperoleh perusahaan?

AA : ya kan ini pak, pada masalah nyari keuntungan pastinya maksimal berarti harus dihitung semua kemungkinan yang ada baru ditentukan keuntungan maksimalnya.

Q : Why can you determine the amount of money the company gets?

AA : Yes, sir, on the problem of finding the maximum profit, it means that you have to calculate all the possibilities, the maximum profit is determined.

Based on these data, it shows that students must have good accuracy to evaluate each sentence on the problem[14] because this process will be used to make decisions in the inference process.

\subsection{Inference}

The inference conducted by AA on the problem was good. From the answers given by subject, able to give conclusions based on the calculation process. The accuracy of the results is influenced by the evaluation carried out. Problem-solving process, a review of the question solution was needed with the direction of the teacher[3].

\subsection{Explanation}

Based on the answer and the interview, the subject was asked to explain the steps taken to solve the problem again. The results obtained indicate that the subject can solve the problem and can explain it well. It showed characteristic meaning-based approach when solved the problems[15]. In this stage, the subject feels confident about the results.

\subsection{Self-regulation}

From the interview, it appears that the subject is confident with the results done. But after the researchers explored further, it turned out that AA only realized that what he did was an error. Self-regulation promotes success in academic learning, especially in operational research[16]. The result of this research in accordance with the finding of the previous research [14] they explain that CTL strategies are likewise fundamental in emphasizing critical thinking, 
recognizing the requirement of teaching and learning in the different context, motivating the students to study each other and employing authentic evaluation Additionally, some scholars found that

\section{Conclusion and Policy Recommendations}

From the results of the study, it was found that subjects with middle critical thinking's skill were able to solve operational research problems well. This is based on six components of critical thinking. Based on the results of AA analysis, it was able to show six indicators to think critically well, even though AA made a mistake in the calculation process. The error was made by AA when it mistranslated the symbol of a mathematical operation.

The results of this study suggest that for lecturers, prospective lecturers, and other researchers about critical thinking skills in management students in completing operational research problems. For lecturers, it is appropriate to use problems that involve critical thinking of students in the learning process. In addition, other researchers can develop learning models that teach critical thinking in other subjects and use Contextual Teaching and Learning (CTL).

Acknowledgments. We thank our colleagues from Universitas PGRI Adi Buana Surabaya who provided insight and expertise that greatly assisted the research, although they may not agree with all of the interpretations/conclusions of this paper.

\section{References}

[1] J. Wang, Y. C. Fong, and W. A. M. Alwis, "Developing Professionalism in Engineering Students Using Problem Based Learning," in Proceedings of the 2005 Regional Conference on Engineering Education, December 12-13, 2005, Johor, Malaysia, 2005, pp. 396-404.

[2] L. Greenstein, A ssesing 21 st Century Skill, A Guide To Evaluating Mastery and Authentic Learning. USA: Corwin A Sage Company, 2012.

[3] E. Istianah, "Meningkatkan Kemampuan Berpikir Kritis Dan Kreatif Matematik Dengan Pendekatan Model Eliciting Activities (MEAs) Pada Siswa SMA," Infin. J. Ilm. Progr. Stud. Mat. STKIP Siliwangi Bandung, vol. 2, no. 1, pp. 43-54, 2013.

[4] I. M. Suarsana and G. A. Mahayukti, "Pengembangan E-Modul Berorientasi Pemecahan Masalah Untuk Meningkatkan Keterampilan Berpikir Kritis Mahasiswa," J. Pendidik. Indones., vol. 2, no. 2, pp. 264-275, 2013.

[5] F. Fakhriyah, "Penerapan Problem Based Learning Dalam Upaya Mengembangkan Kemampuan Berpikir Kritis Mahasiswa,” J. Pendidik. IPA Indones., vol. 3, no. 1, pp. 95-101, 2014.

[6] F. . D'Alessio, B. E. Avolio, and V. Charles, "Studying the Impact of Critical Thinking on the Academic Performance of Executive MBA Students. Thinking Skills and Creativity," Think. Ski. Creat. J., 2019.

[7] W. Ulrich, "Operations research and critical systems thinking: an integrated perspective. Part 1: O.R. as applied systems thinking," J. Oper. Res. Soc., vol. 63, no. 9, pp. 1228-1247, 2012.

[8] P. . Facione, "Critical Thinking: What It Is and Why It Counts. Insight Assesment," 2010.

[9] J. Natalia, "Analisis Pengelolaan Operasional Dan Total Quality Management Di CV. Star Digital Printing," J. Agora, vol. 4, no. 2, pp. 51-58, 2016.

[10] M. Montague, "Mathematics Problem Solving for Middle School Students with Dissabilities," 2007. [Online]. Available: http:/www.k8accesscenter.org/trainingresouces/ MathProblemSolving.asp.

[11] M. Blanton et al., "A Learning Trajectory in 6-Year-Olds ' Thinking About Generalizing Functional Relationships," J. Res. Math. Educ. 2015, vol. 46, no. 5, pp. 511-558, 2015. 
[12] T. L. Adams, "More than Words Can Say. The Reading Teacher," Read. Teach. J., vol. 56, no. 8, pp. 786-795, 2003.

[13] M. N. B. B. Bakry, "The Process of Thinking among Junior High School Students in Solving HOTS Question," Int. J. Eval. Res. Educ., vol. 4, no. 3, pp. 138-145, 2015.

[14] V. Selviana, A. R. Asari, and M. Muksar, "Kemampuan Berpikir Kritis Siswa SMK dalam Menyelesaikan Masalah Kombinatorika dan Peluang Kemampuan Berpikir Kritis Siswa SMK dalam Menyelesaikan Masalah Kombinatorika dan Peluang," in Seminar PPG SM-3T UM 2016, 2016, pp. 529-535.

[15] S. J. Pape, "Middle School Children's Problem-Solving Behavior: A Cognitive Analysis from a Reading Comprehension Perspective," J. Res. Math. Educ., vol. 35, no. 3, pp. 187-219, 2004.

[16] F. K. Fadlelmula, "Mathematical problem solving and self-regulated learning," Int. J. Learn., vol. 17, no. 3, 2010. 